\title{
Targeting HIF2a Translation with Tempol in VHL-Deficient Clear Cell Renal Cell Carcinoma
}

\author{
Carole Sourbier ${ }^{1, *}$, Gaurav Srivastava ${ }^{1, *}$, Manik C. Ghosh ${ }^{2}$, Sanchari Ghosh ${ }^{1}$, \\ Youfeng Yang1, Gopal Gupta ${ }^{1}$, William DeGraff ${ }^{3}$, Murali C. Krishna ${ }^{3}$, James B. \\ Mitchell $^{3}$, Tracey A. Rouault ${ }^{2}$, W. Marston Linehan ${ }^{1}$ \\ ${ }^{1}$ Urologic Oncology Branch, Center for Cancer Research, National Cancer Institute \\ ${ }^{2}$ National Institute of Child Health and Human Development \\ ${ }^{3}$ Radiation Biology Branch, Center for Cancer Research, National Cancer Institute, National Institutes of Health, Bethesda, \\ MD \\ * Authors contributed equally to this work.
}

Correspondence to: W. Marston Linehan, email: WML@nih.gov

Keywords: HIF, Tempol, RCC, VHL, IRPI, iron metabolism

Received: July 19, 2012, Accepted: November 06, 2012, Published: November 08, 2012

Copyright: ( ) Sourbier et al. This is an open-access article distributed under the terms of the Creative Commons Attribution License, which permits unrestricted use, distribution, and reproduction in any medium, provided the original author and source are credited.

\section{ABSTRACT:}

The tumor suppressor gene, Von Hippel-Lindau (VHL), is frequently mutated in the most common form of kidney cancer, clear cell renal cell carcinoma (CCRCC). In hypoxic conditions, or when there is a $V H L$ mutation, the hypoxia inducible factors, HIF1a and HIF2a, are stabilized and transcribe a panel of genes associated with cancer such as vascular endothelial growth factor receptor (VEGFR), platelet derived growth factor (PDGF), and glucose transporter 1 (GLUT1). Recent studies in clear cell kidney cancer have suggested that HIF2a, but not HIF1a, is the critical oncoprotein in the VHL pathway. Therefore, targeting HIF2a could provide a potential therapeutic approach for patients with advanced CCRCC. Since iron regulatory protein 1 (IRP1) is known to inhibit the translation of HIF2a, we investigated whether Tempol, a stable nitroxide that activates IRP1 towards IRE-binding, might have a therapeutic effect on a panel of human CCRCC cells expressing both HIF1a and HIF2a. We first evaluated the protein expression of HIF1a and HIF2a in 15 different clear cell renal carcinoma cell lines established from patient tumors in our laboratory. Tempol decreased the expression of HIF2a, and its downstream targets in all the cell lines of the panel. This effect was attributed to a dramatic increase of IRE-binding activity of IRP1. Several cell lines were found to have an increased IRP1 basal activity at $20 \% \mathrm{O}_{2}$ compared to $5 \% \mathrm{O}_{2}$, which may lower HIF2a expression in some of the cell lines in a VHL-independent manner. Taken together our data identify Tempol as an agent with potential therapeutic activity targeting expression of HIF2a in VHL-deficient clear cell kidney cancer and illustrate the importance of studying biochemical processes at relevant physiological 02 levels.

\section{INTRODUCTION}

In the United States, an estimated 64,770 new cases of kidney cancers will be diagnosed in 2012 and about 13,570 people will die of this disease [1]. The most common type of kidney cancers, clear cell renal cell carcinoma (CCRCC), is associated with mutations of the $V H L$ gene $[2,3,4]$. In normal tissues, the product of the $V H L$ gene is associated with ubiquitination and degradation of the hypoxia inducible factor (HIF) through an oxygen-sensing mechanism [5,6]. In normoxia, HIF1 $\alpha$ and HIF $2 \alpha$ are hydroxylated by prolyl-hydroxylases in an iron-dependent manner. This post-translational modification allows recognition of HIF by the VHL complex and leads to its degradation by the proteasome $[7,8]$. However, in the absence of oxygen, or in the 
presence of a mutated $V H L$ gene, HIF $1 \alpha$ and HIF $2 \alpha$ are stabilized and induce the expression of a panel of transcriptional target genes such as VEGF, PDGF, and GLUT1, supporting the metabolic shift that underlies CCRCC tumorigenicity [9]. Even in presence of oxygen, clear cell kidney cancer cells with $V H L$ gene mutation display a "pseudo-hypoxic" phenotype. Although the degradation of both HIF $1 \alpha$ and HIF $2 \alpha$ are regulated by VHL $[10,11]$, HIF $2 \alpha$ has been thought to be the dominant oncoprotein in VHL-deficient CCRCC cells $[12,13,14]$. It was also recently suggested that HIF $1 \alpha$ may function as a tumor suppressor gene in VHL-deficient clear cell kidney cancer [15]. However, despite the proposed critical role of HIF $2 \alpha$ in VHL-deficient CCRCC tumorigenesis, only a few HIF2 $\alpha$ inhibitors have been described [16,17].

A molecular link between HIF $2 \alpha$ expression and iron availability has recently been reported [18]. HIF $2 \alpha$, but not HIF1 $\alpha$, has an iron-responsive element (IRE) in the 5 ' untranslated region (UTR) of its mRNA. Thus, when the cells are deficient in iron, the iron regulatory proteins (IRPs) repress the translation of HIF $2 \alpha$ protein by binding to its 5'IRE. In addition, Ghosh et al. have recently shown that a stable nitroxide, Tempol (4-hydroxy-2,2,6,6tetramethylpiperidine-N-oxyl) partially restored the phenotypes of IRP2 knockout mice by activating the IRE binding activity of IRP1 and thus partially compensating for the loss of IRP2 [19].

In this report, using a panel of VHL-deficient CCRCC cell lines that express increased either HIF $1 \alpha$ or HIF $2 \alpha$ or both, we investigated whether Tempol inhibits the translation of HIF $2 \alpha$ by inducing the IRE binding activity of IRP1 and whether Tempol might be a potential targeted therapy for CCRCC.

\section{RESULTS}

\section{HIF1 $\alpha$ and HIF2 $\alpha$ expression in CCRCC cell lines.}

We first characterized the HIF $\alpha$ status of 15 RCC cell lines with mutated $V H L$ gene (Figure 1 and Table 1).
All of the cells expressed HIF2 $\alpha$, but some, including 7860 [7], UOK111, UOK121 and UOK151 did not express HIF $1 \alpha$ or expressed a shorter $75 \mathrm{kDa}$ splice isoform. Interestingly although expressed in UOK 154 , HIF $2 \alpha$ protein levels were low relative to other $V H L$-deficient cells.

\section{Tempol decreases HIF $2 \alpha$ protein expression and inhibits its downstream targets.}

We then assessed the effect of Tempol on HIF $1 \alpha$ and HIF $2 \alpha$ protein levels. Tempol decreased HIF $1 \alpha /$ HIF $2 \alpha$ levels in 786-0 cell line, which expresses only HIF $2 \alpha$ [7], and in UOK220 cell line, which expresses both HIF $\alpha$ isoforms (Figure 2). The reduced form of Tempol (Tempol-H), which was used as a negative control, had no effect on either HIF $1 \alpha$ or HIF $2 \alpha$ expression (Figure 2). To further investigate the effect of Tempol on HIF $\alpha$ activity and pathway, we assessed the level of nuclear HIF2 $\alpha$ following Tempol treatment (5mM, 24h; Figure $3 \mathrm{~A}$, supplementary figure 1 ). Using $30 \mu \mathrm{g}$ of nuclear extracts and similar to that observed in the previous experiment, Tempol significantly decreased the level of nuclear HIF2 $\alpha$, suggesting that its transcriptional activity was also compromised. The effect of Tempol on nuclear HIF $1 \alpha$ expression was, however, not consistent in all of the cell lines (Figure 3, supplementary figure 1). We then evaluated the expression of HIF $2 \alpha$ downstream targets following Tempol's treatment. In 786-0 and UOK220 cells, both CA-9 expression and VEGF secretion, two known HIF $2 \alpha$ targets and therapeutic targets for CCRCC $[20,21]$, were found to be decreased after $24 \mathrm{~h}$ of treatment with 5mM Tempol (Figure 3B-C). Also, since HIF $\alpha$ is known to play a role in regulating tumor cells metabolism, we asked whether Tempol might have a metabolic effect on 786-0 cells. As shown in Figure 3D and consistent with our observation that Tempol's effect on HIF $\alpha$ is mainly on HIF2 $\alpha$, Tempol (24h, $5 \mathrm{mM})$ did not affect the extra-cellular acidification rate of 786-0 cells (ECAR), a surrogate for lactate secretion. This is consistent with other published works, such as the recent paper of Chiavarina et

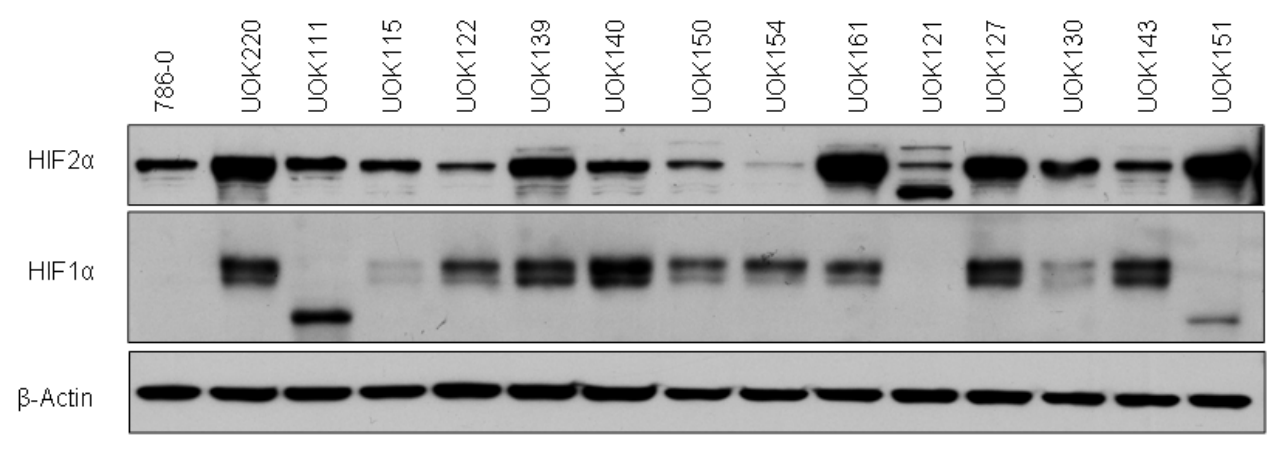

Figure 1: Characterization of the HIF $\alpha$ status of CCRCC cells. Protein expression of HIF $1 \alpha$ and HIF $2 \alpha$ was assessed by immunoblotting. Fifteen different CCRCC cell lines (80\% confluence) were lysed in TNSEV buffer, subjected to SDS-PAGE (20 $\mu$ g of whole cell lysates per well), transferred to PVDF membrane, and immunoblotted for HIF1 $\alpha$ and HIF2 $\alpha$ protein expression. 
Table 1: CCRCC cell lines HIF status. Summary of the CCRCC cell lines and normal epithelial kidney cell line with their VHL mutation and their HIF status. NA: not available. Short: a $75 \mathrm{kD}$ isoform of HIF $1 \alpha$ is expressed but not the full length.

\begin{tabular}{|c|c|c|c|c|}
\hline & Tissue Type & VHL Mutation & 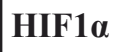 & HIF2 $\alpha$ \\
\hline UOK111 & Clear & missense $\mathrm{T}>\mathrm{A}$ Trp117Arg & Short & Yes \\
\hline UOK115 & Clear & frameshift Del_TG Pro103 & Yes & Yes \\
\hline UOK121 & Clear & $\mathrm{A}>\mathrm{G}$ splice exon $2 /$ methylated & No & Yes \\
\hline UOK122 & Clear & nonsense $\mathrm{C}>\mathrm{T}$ Arg113stop & Yes & Yes \\
\hline UOK127 & NA & 2 hyper-methylated copies & Yes & Yes \\
\hline UOK130 & NA & $\begin{array}{l}\mathrm{T}>\mathrm{C} \text { at NT. 671, Leu153Pro missense mt } \\
(\text { exon } 2)\end{array}$ & Yes & Yes \\
\hline UOK139 & Clear & frameshift Del_A Thr 157 & Yes & Yes \\
\hline UOK 140 & Clear & frameshift Del_A Asp126 & Yes & Yes \\
\hline UOK 143 & Clear & $\mathrm{A}>\mathrm{G}$ at 235 splice exon 2 & Yes & Yes \\
\hline UOK 150 & Clear & Ins_C at 447 Tyr98; $\mathrm{T}>\mathrm{A}$ at 448 Tyr98 & Yes & Yes \\
\hline UOK151 & Clear & nonsense $\mathrm{C}>\mathrm{T}$ Ser183stop & Short & Yes \\
\hline UOK154 & Clear & Ins_A Gln203 & Yes & Yes \\
\hline UOK161 & Clear & $\mathrm{C}>\mathrm{T}$ Gln164stop & Yes & Yes \\
\hline UOK220 & Clear & 2 missense $\mathrm{T}>$ A Asn78Lys C $>$ T Arg79Cys & Yes & Yes \\
\hline $786-0$ & Clear & $\begin{array}{l}1 \text { bp Del at NT. } 523, \\
\text { frameshift at Gly104, exon } 1\end{array}$ & No & Yes \\
\hline HK2 & Normal & None & No & No \\
\hline
\end{tabular}

al which shows that HIF $1 \alpha$ and not HIF $2 \alpha$ is important for glycolysis in a breast cancer model [22]. Further, the effect of Tempol on HIF $2 \alpha$ expression and on its downstream targets was highly reproducible since it was also observed in 12 other CCRCC cell lines displaying various HIF1 $\alpha$ and HIF $2 \alpha$ expression patterns (Figure 4 and Figure 1). Thus, our data suggest that Tempol is a potent HIF2 $\alpha$ inhibitor, regardless of the HIF $1 \alpha$ status of the CCRCC cell line studied.

\section{Tempol's effect on IRP1 activity correlates with HIF $2 \alpha$.}

To further investigate Tempol's mechanism of action and how it decreases HIF2 $\alpha$ expression, we first assessed whether Tempol might have an effect on HIF2 $\alpha$ at a transcriptional level. We quantified HIF $2 \alpha$ mRNA levels following Tempol treatment by semi-quantitative RT-PCR. As shown in Figure 5A, 24h of Tempol treatment did not significantly change the mRNA expression of HIF2 $\alpha$. Then,in order to assess whether Tempol might have an effect on HIF $2 \alpha$ by inducing its degradation, we evaluated the effect of Tempol (5mM, 24h) on HIF $2 \alpha$ expression following inhibition of the proteasome with velcade $(1 \mu \mathrm{M}$, $24 \mathrm{~h})$. As shown in figure $5 \mathrm{~B}$, using $20 \mu \mathrm{g}$ of whole cell lysates, Tempol still decreased HIF $2 \alpha$ protein expression, suggesting that Tempol's effect on HIF $2 \alpha$ happened at the translational level. Because HIF2 $\alpha$ expression and iron availability have recently been linked [18] and that Ghosh et al. have shown that Tempol is able to activate the IRE binding activity of IRP1[19], we thus investigated Tempol's effect on iron availability and IRP1 activity. We measured the amount of $\mathrm{Fe}^{2+}$ in cells following Tempol treatment as the nitroxide agent Tempol is able to lower $\mathrm{Fe}^{2+}[23]$. As shown in Figure 5C, Tempol significantly decreased the amount of available $\mathrm{Fe}^{2+}$. In addition, Tempol increased IRP1 activity in a panel of CCRCC cell lines (Figure 5D-E), which inversely correlated with HIF2 $\alpha$ expression (Figure $5 \mathrm{~F}, \mathrm{R}^{2}=1$ ). Taken together these data suggest that Tempol regulates HIF2 $\alpha$ expression at the translational level by increasing the IRE binding activity of IRP1. Interestingly, the basal level of IRP1 activation was highly increased in most of the cell lines at $21 \% \mathrm{O}_{2}$ (Table 2) [24], suggesting that the $\mathrm{O}_{2}$ environment of the cell culture in vitro also affects HIF $\alpha$ expression in $V H L$ deficient cells. 


\section{Tempol is cytotoxic to CCRCC cells.}

Due to the observed effect of Tempol on HIF $2 \alpha$, CA9 and VEGF, all previously reported therapeutic targets for CCRCC tumors, we investigated whether Tempol might have an anti-tumor effect in CCRCC cells. Cell cytotoxicity assays demonstrated that $48 \mathrm{~h}$ treatment with Tempol is cytotoxic to CCRCC cells in vitro (Figure 6A), that Tempol inhibits the formation of colonies of 786-0 cells (Figure 6B), and inhibits the proliferation of CCRCC cells 786-0 and UOK220 (Figure 6C). Also, Tempol treatment $(5 \mathrm{mM})$ decreased by $50 \%$ the ability of $786-0$ cells to form anchorage-independent colonies, a marker of tumor transformation assessed by soft-agar colony formation assay (6D).

\section{DISCUSSION}

Targeting HIF $2 \alpha$ is of particular interest in cancer therapy since HIF $2 \alpha$ is the transcription factor of numerous genes that have been involved not only in the development of CCRCC growth $[20,21,25,26]$ but also in the development of other type of tumors [27,28]. However, to date, only few HIF $2 \alpha$ inhibitors have been identified. In this report, we identified the nitroxide Tempol as a potent HIF2 $\alpha$ inhibitor, with promising anti-tumor effects in a panel of CCRCC tumor cell lines.

Mutations occurring on the $V H L$ gene are a critical event leading to CCRCC development in both sporadic and hereditary forms of kidney tumors. This lack of VHL function leads to the stabilization of both HIF $1 \alpha$ and HIF $2 \alpha$ proteins as well as to an increase in DNA damage $[10,11,29]$. Although the expression of both HIF $1 \alpha$ and HIF $2 \alpha$ is similarly regulated by VHL, their roles in tumor development, tumor metabolism, and response to therapy are sometimes contrasted [12,22,30,31]. Thus, although our goal was to identify a new HIF $2 \alpha$ inhibitor, we characterized the expression status of both HIF $1 \alpha$ and HIF2 $\alpha$ in 15 VHL-deficient clear cell kidney cancer cell lines and assessed the effect of Tempol on both HIF $\alpha$ isoforms. Regardless of the differences in HIF $1 \alpha$ and HIF $2 \alpha$ expression between CCRCC cell lines, Tempol decreased the expression and function of HIF2 $\alpha$ in all the cell lines. Surprisingly, Tempol also decreased the protein

A.

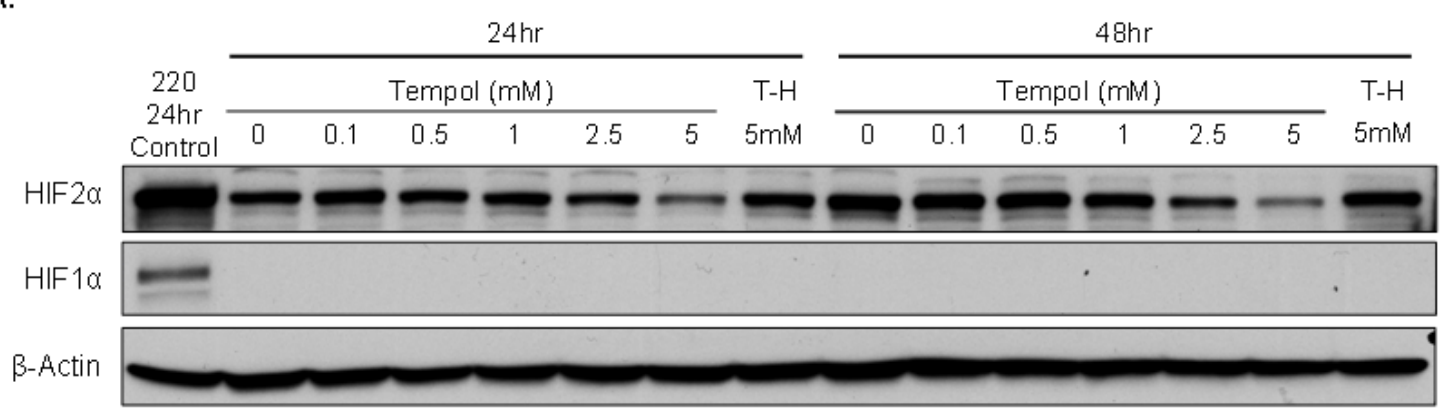

B.

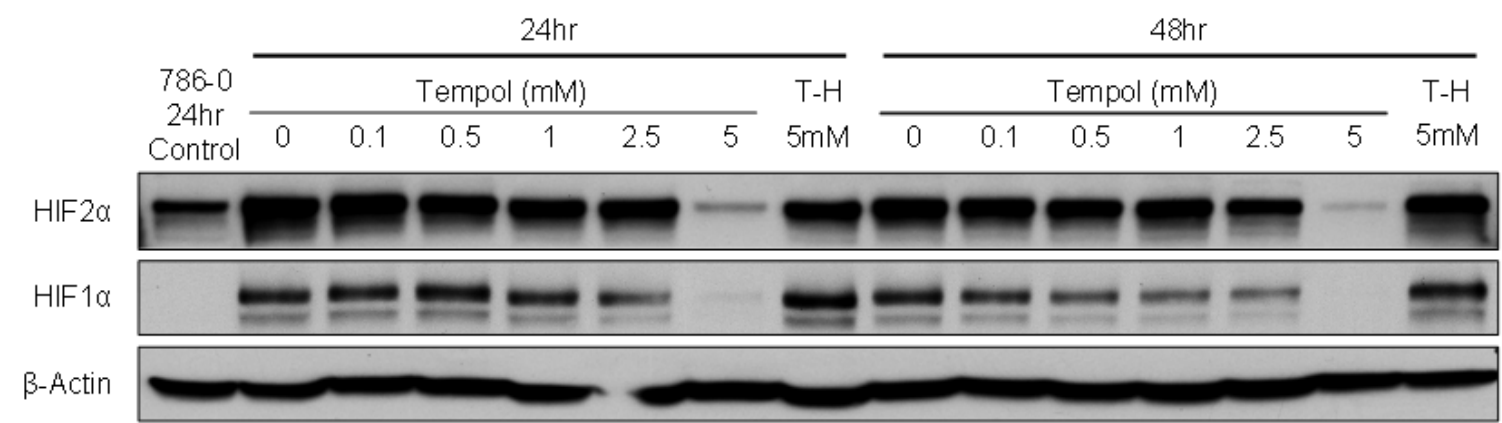

Figure 2: Tempol decreases HIF $\alpha$ expression. A. To assess the effect of Tempol on HIF $\alpha$ expression in CCRCC cells, 786-0 cells were treated with several concentrations of Tempol for $24 \mathrm{~h}$ or $48 \mathrm{~h}$ before to be subjected to whole protein lyses, SDS-PAGE and immunoblotting for both HIF $\alpha$ isoforms. As previously reported 786-0 cells do not express HIF1 $\alpha$ protein [7]. The CCRCC cell line UOK 220 cell was used as a positive control for HIF $1 \alpha$ and HIF2 $\alpha$ antibodies. The reduced form of Tempol (hydroxy-Tempol, T-H) was also used as a negative control. B. A similar treatment regiment using Tempol was made using UOK220 cell line, a CCRCC cell line expressing both HIF $1 \alpha$ and HIF $2 \alpha$. We used untreated lysates of 786-0 as a negative control for the HIF1 $\alpha$ antibody and as a positive control for the HIF $2 \alpha$ antibody. The reduced form of Tempol (hydroxy-Tempol, T-H) was also used as a negative control. 
A.

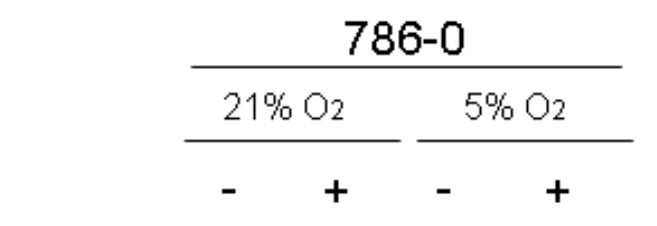

$\mathrm{HIF} 2 \alpha$

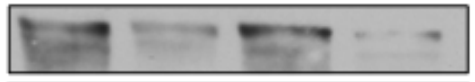

$\mathrm{HIF} 2 \alpha$

$\mathrm{HIF} 1 \alpha$

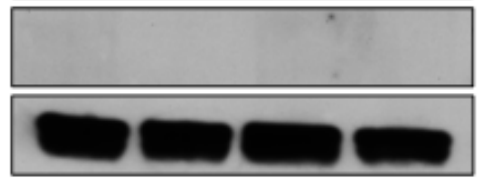

$H I F 1 \alpha$

CREB

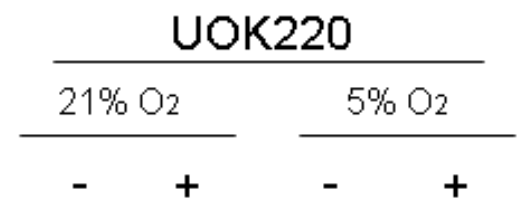

CREB
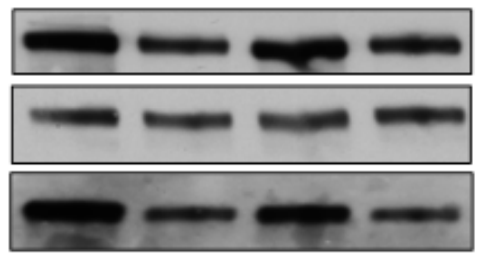

$B$.

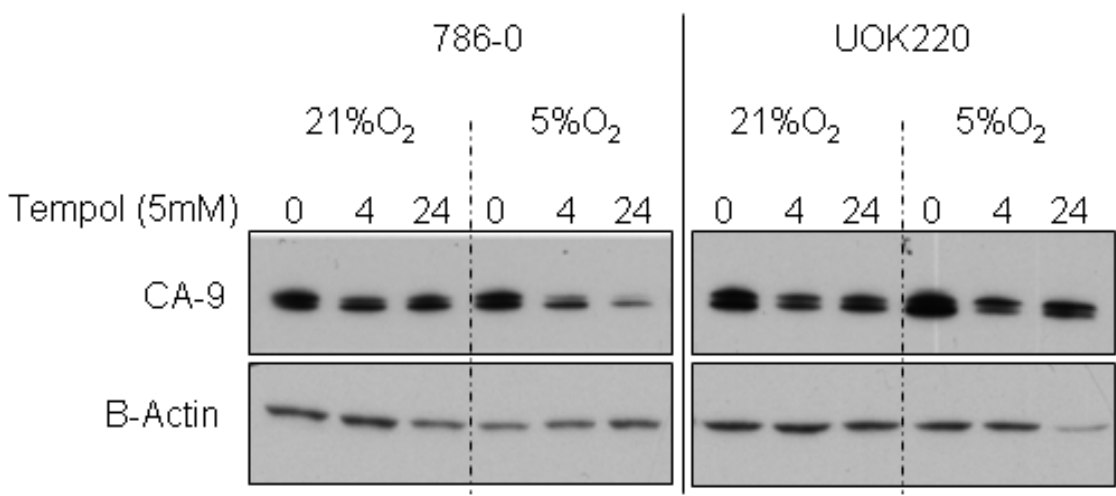

C.

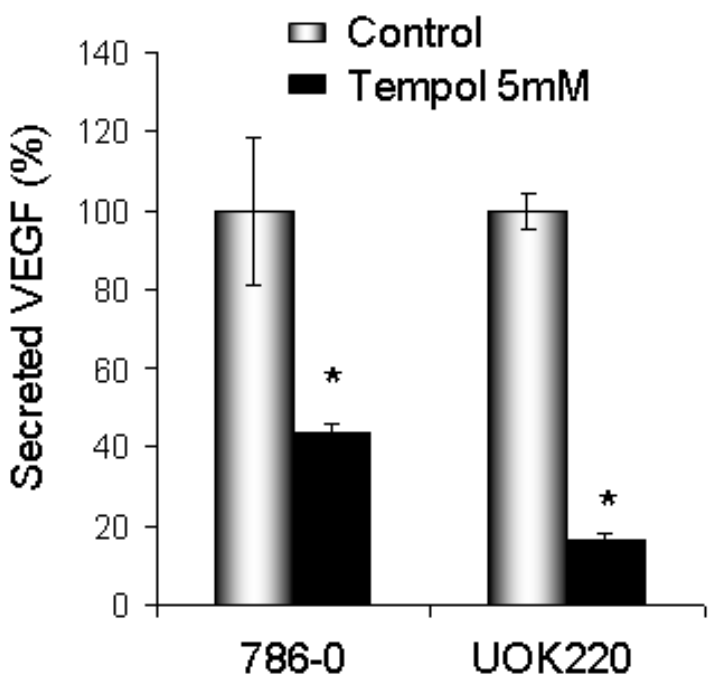

D.

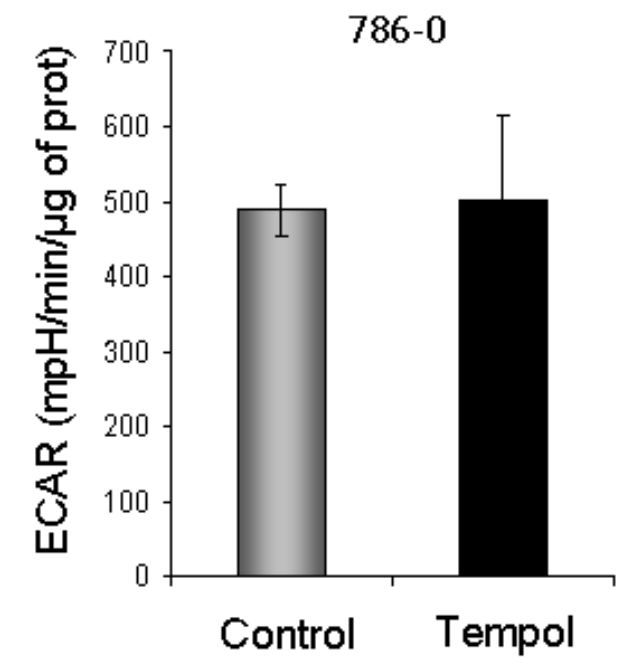

Figure 3: Tempol decreases HIF2 $\alpha$ nuclear activity. A. To assess the effect of Tempol on HIF $\alpha$ nuclear activities, expression of $\mathrm{HIF} \alpha$ was assessed in 786-0 and UOK220 cells following Tempol treatment $(5 \mathrm{mM}, 24 \mathrm{~h})$ and using $30 \mu \mathrm{g}$ nuclear lysates extracted at $21 \%$ or $5 \% \mathrm{O}_{2}$. B. The effect of Tempol treatment $(5 \mathrm{mM}, 24 \mathrm{~h}$ ) on the HIF $2 \alpha$ transcriptional target, carbonic anhydrase 9 (CA-9), was visualized by immunoblotting using $20 \mu \mathrm{g}$ of whole cell extracts (786-0 and UOK220 cells). C. The effect of Tempol on another HIF2 $\alpha$ transcriptional target VEGF was assessed by measuring the amount of VEGF secreted in the media of 786-0 and UOK220 cells after Tempol treatment (5mM, 24h). Secreted VEGF was quantified by ELISA using the MesoScale discovery (MSD) technology. D. The effect of Tempol on 7860 cells' metabolism was assessed using the Seahorse Bioscience technology. 
expression and activity of HIF $1 \alpha$ in some of the CCRCC cell lines. As HIF1 $\alpha$ does not have an IRE-binding domain, the reasons underlying Tempol's effect on HIF $1 \alpha$ remain unknown, especially as it was inconsistent throughout the panel. Also, further work will be necessary to assess whether this effect on HIF $1 \alpha$ might be beneficial or not for the survival of the tumors. Nevertheless, Tempol's effect on HIF $2 \alpha$ was consistent in all the tested CCRCC cell lines regardless its effect on HIF $1 \alpha$.

The presence of an iron-responsive
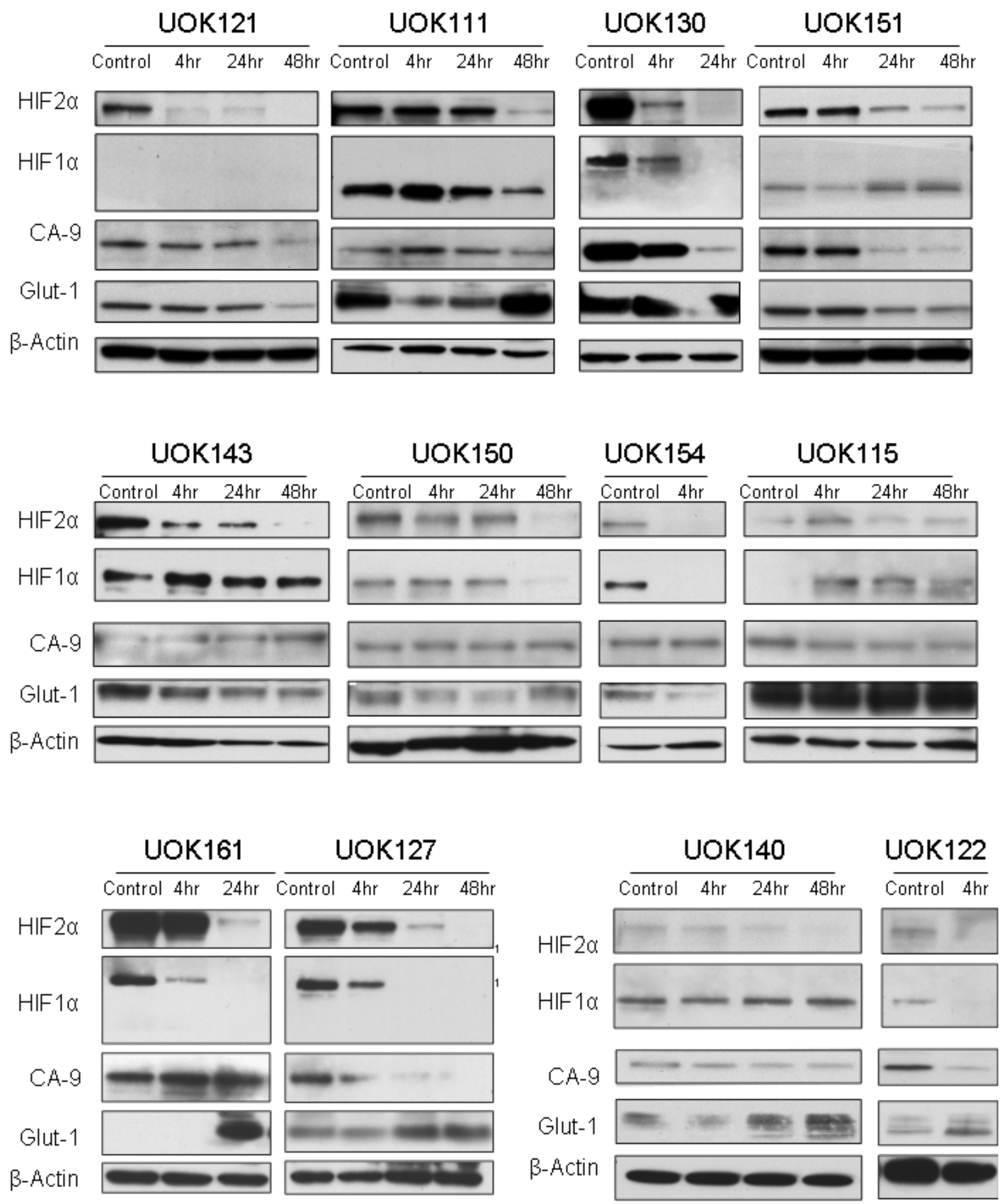

Figure 4: Tempol inhibits HIF2 $\alpha$ in a panel of CCRCC cells. Twelve CCRCC cell lines were treated with $5 \mathrm{mM}$ Tempol for $4 \mathrm{~h}, 24 \mathrm{~h}$ or $48 \mathrm{~h}$ before to be subjected to whole protein lysis, SDS-PAGE and immunoblotting for both HIF $\alpha$ isoforms and CA-9. Twenty micrograms of whole cell extracts were used for loading the gels. 
A.

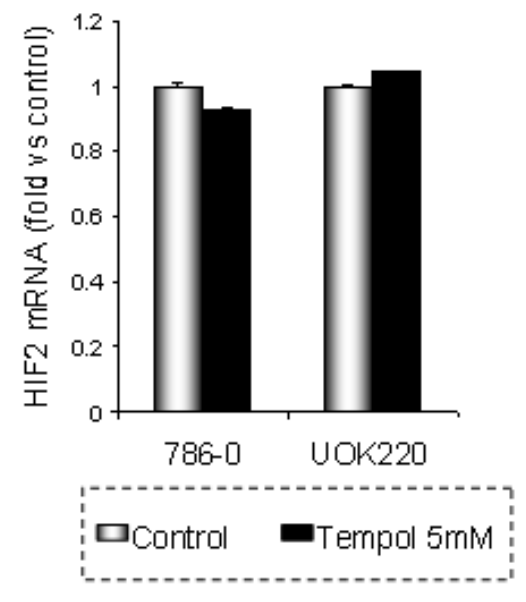

C.

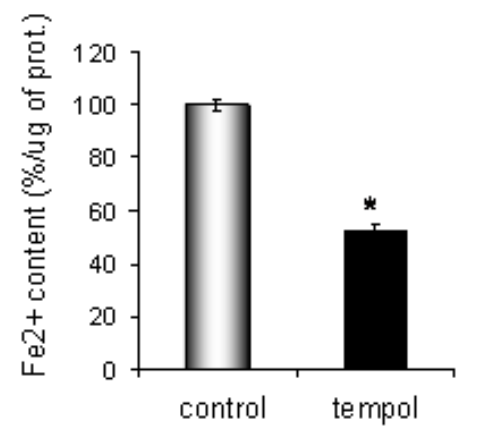

E.
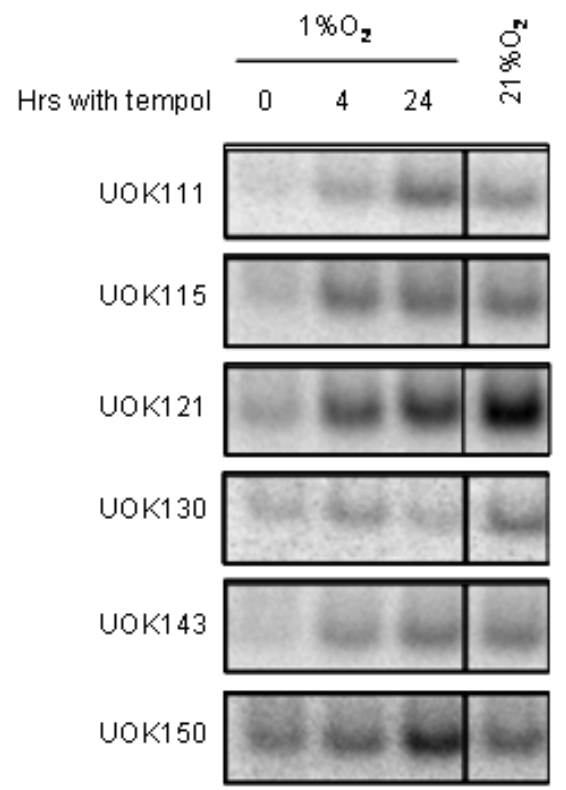

UOK161
B.

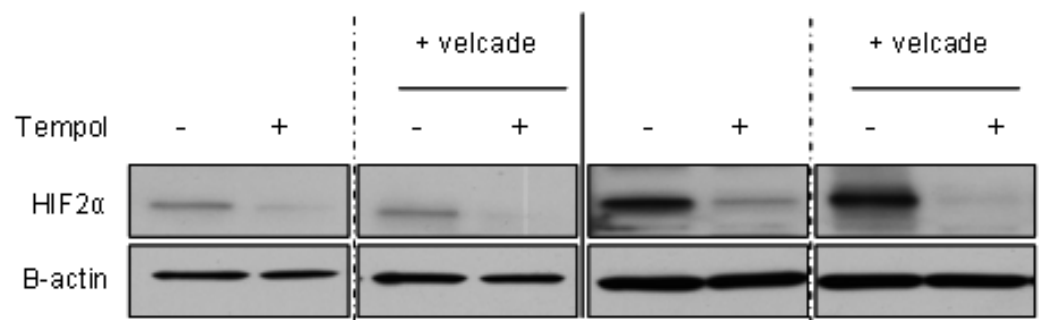

D.

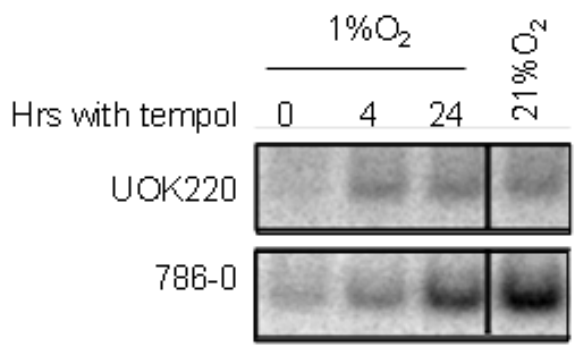

$\mathrm{F}$.

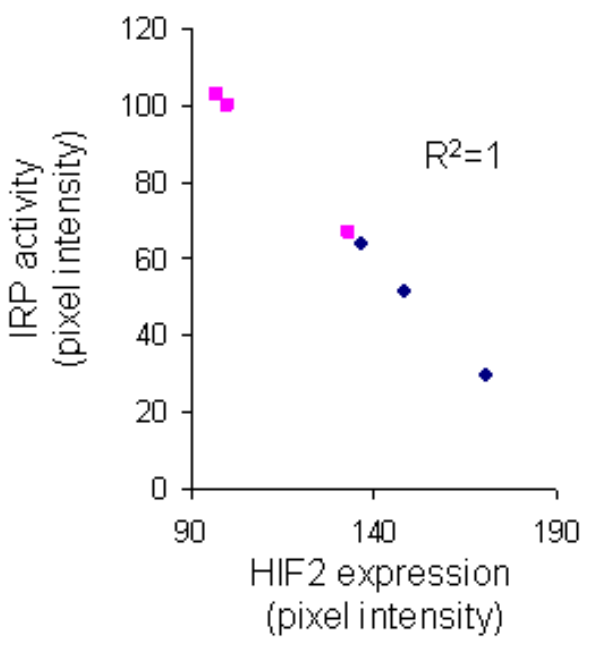

Figure 5: Tempol translationaly inhibits HIF2 $\alpha$. A. The effect of Tempol (5mM, 24h) on HIF2 $\alpha$ transcription was assessed by semi-quantitative RT-PCR in 786-0 and UOK220 cells. B. The effect of Tempol (5mM, 24h) on HIF2 $\alpha$ protein degradation was assessed by treating the cells with the proteasome inhibitor velcade $(1 \mu \mathrm{M}, 24 \mathrm{~h})$. HIF $2 \alpha$ expression was then assessed by immunoblotting using $20 \mu \mathrm{g}$ of whole cell lysates. C. The amount of available ferrous iron $\left(\mathrm{Fe}^{2+}\right)$ content was measured after Tempol treatment (5mM, 24h) in 786-0 cells. D-E. IRP1 activities of different CCRCC cell lines were measured at $1 \%$ and $21 \% \mathrm{O}_{2}$ and following Tempol treatment (5mM, 24h). F. Correlation between HIF2 $\alpha$ expression and IRP1 activity $\left(\mathrm{R}^{2}=1\right)$. 
Table 2: Ratio of IRP1 activity status $(21 \%$ to $1 \%)$ in CCRCC cell lines.

\begin{tabular}{|l|l|l|}
\hline Cells & $\begin{array}{l}\text { Tissue } \\
\text { Type }\end{array}$ & $\begin{array}{l}\text { IRP1 activity at } \\
\mathbf{2 0 \%} \text { O2 } \begin{array}{r}\text { (fold } \\
\text { compared to 1\%O2) }\end{array}\end{array}$ \\
\hline UOK111 & Clear & 7.87 \\
\hline UOK130 & NA & 2.3 \\
\hline UOK143 & Clear & 3.26 \\
\hline UOK150 & Clear & 1.2 \\
\hline UOK161 & Clear & 2.06 \\
\hline UOK220 & Clear & 2.2 \\
\hline 786-0 & Clear & 3.6 \\
\hline
\end{tabular}

element in the 5'-UTR of HIF $2 \alpha$ mRNA regulating HIF $2 \alpha$ translation (but not HIF $1 \alpha$ ) links HIF $2 \alpha$ and iron metabolism. This also opens new therapeutic strategies to selectively target HIF $2 \alpha$. When Ghosh and collaborators demonstrate that Tempol is able to activate the IRE binding activity of IRP1[19], we thus hypothesized that Tempol might also be able to inhibit HIF2 $\alpha$ translation. In this report, we demonstrated that the decrease in expression of HIF2 $\alpha$ following Tempol treatment significantly correlated with an increased activation of IRP1, reinforcing the link between IRP1 activity and HIF2 $\alpha$ expression. Moreover, Tempol treatment decreased CCRCC cells viability, clonogenicity, proliferation, as well as anchorage-independent growth. Thus, by regulating the iron metabolism of CCRCC cells, Tempol may have a potential therapeutic value for cancers dependent on HIF2 $\alpha$ for growth and survival, such as CCRCC tumors.

Interestingly, at $21 \% \mathrm{O}_{2}$, most of the CCRCC cell lines (with the exception of UOK150) were found to have an artificially high level of IRP1 activity (Table2). This suggests that culturing CCRCC cells at $21 \% \mathrm{O}_{2}$ may artificially lower HIF $2 \alpha$ expression in a $V H L$-independent manner by oxidizing the $[4 \mathrm{Fe}-4 \mathrm{~S}]$ center in aconitase, and therefore, activating the IRE-binding form of IRP1. These findings highlight the importance of working in an in vitro condition that properly recreates the in vivo tumor environment [24].

Although significant progress in understanding the genetic basis of kidney cancer has been made over the past twenty years, there is still a need for the development of effective forms of therapy for patients with advanced kidney cancer. Since the identification of the VHL gene, seven novel agents that target the VHL pathway have been approved by the FDA. However, there are few complete responses to these agents and most patients develop resistance to therapy and develop progressive disease. Targeting HIF $2 \alpha$ with an agent such as Tempol has the potential to inhibit the oncoprotein critical to clear cell kidney cancer carcinogenicity. The findings in this work may provide the foundation for the development of effective forms of therapy for this and other HIF $2 \alpha-$ dependent cancers.

\section{METHODS}

\section{Cell lines and cell culture}

The UOK cell lines (UOK-111, 115, 121, 122, 127, $130,139,140,143,150,151,154,161$, and UOK220) were established in the Urologic Oncology Branch (National Cancer Institute, Bethesda, MD) [32]. 786-0 and HK-2 were obtained from ATCC. Cells were cultured in high glucose DMEM supplemented with 10\% FBS. Cells were harvested or treated when they reached $70-80 \%$ confluence.

\section{Chemical agents}

Tempol and hydroxyl-Tempol were purchased from Sigma-Aldrich (St Louis, MO).

\section{Immunoblotting}

Ten to thirty micrograms of protein was loaded in $4-20 \%$ polyacrylamide gels (Biorad, Hercules, CA). After elelectropheresis, the proteins were transferred on PVDF membranes before being blocked with 5\% fat-free milk for at least $1 \mathrm{~h}$. Primary antibodies were incubated over-night at $4^{\circ} \mathrm{C}$. After serial washes with TBS-Tween, Horseradish peroxidase-linked secondary antibodies (Sigma-Aldrich) were incubated 1-2h before development with the ECL protein detection system (Pierce, Rockford, IL). Goat anti-HIF $2 \alpha$ antibody was obtained from R\&D Systems (Minneapolis, MN). Rabbit antibodies against $\beta$-actin, and carbonic anhydrase 9 (CA9) were from Cell Signaling Technology, Inc. (Danvers, MA). Mouse HIF1 antibody was from BD Transduction (San Jose, CA). All the antibodies were used at 1:1000 dilution.

\section{Cell cytotoxicity}

Cell cytotoxicity was measured using the tetrazolium salt 3-(4,5-dimethylthiazol-2-yl)-2,5diphenyltetrazolium bromide (MTT), as previously described [33]. Briefly, 5,000 cells were seeded into 96well plate and treated as described in the results or figure legends. After $48 \mathrm{hrs}$, the MTT salt was added into the media $(1: 10)$ and incubated for $2 \mathrm{hrs}$ at $37^{\circ} \mathrm{C}$. During that time, metabolically active cells transformed the yellow MTT salt into purple formazan crystals. The media was then removed and the crystals were solubilized in $100 \mu \mathrm{l}$ of DMSO. Data were read at $570 \mathrm{~nm}$. Cell survival was assessed by the clonogenic assay. Exponentially growing cells were exposed to Tempol $(0.1-5.0 \mathrm{mM})$ for $24-72$ hr. Following treatment, cells were trypsinized, counted, plated, and incubated for 10-14 days. Colonies were fixed 
A.

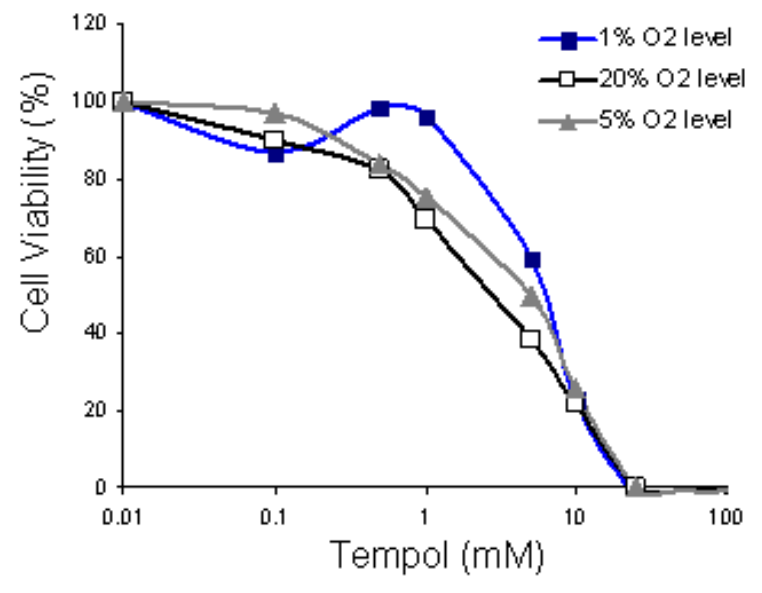

C.

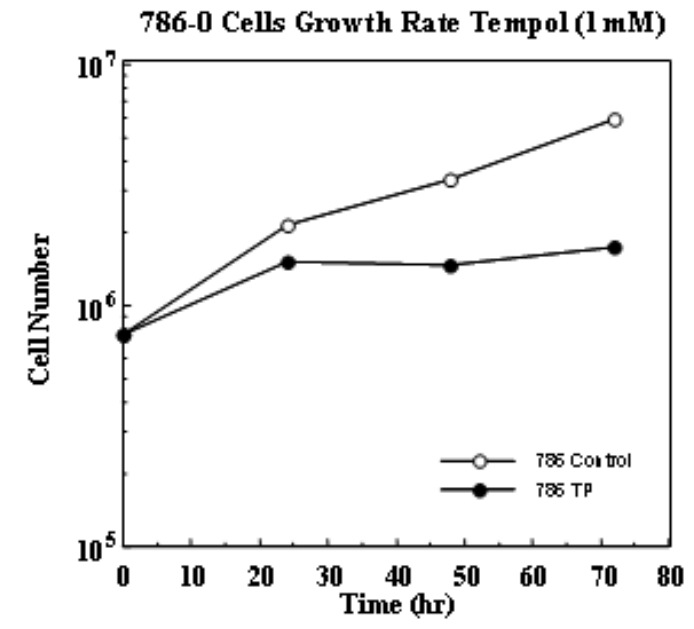

220 Cells Growth Rate Tempol (1 mM)

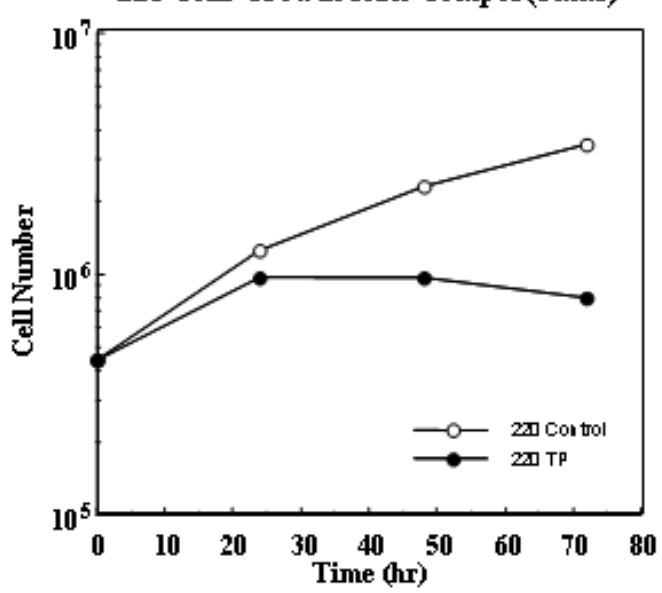

B.

Tempol $0.1 \mathrm{mh}$

Tempol $1.0 \mathrm{mH}$

Tempol $2.5 \mathrm{mH}$

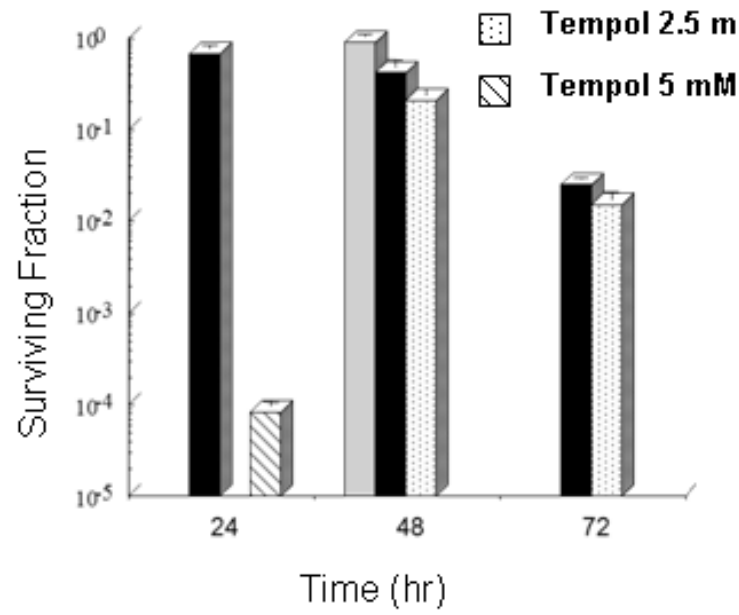

D.

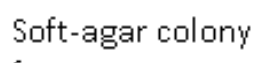

formation assay

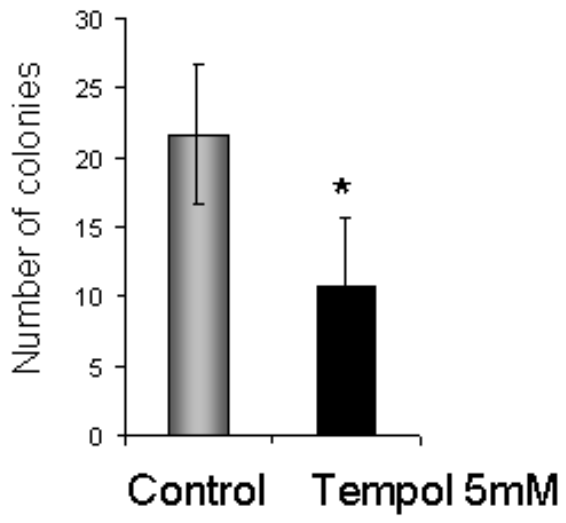

Figure 6: Anti-tumor effect of Tempol in CCRCC. A. The cytotoxic effect of Tempol in 786-0 cells was assessed by MTT after 48h treatment at $1 \%, 5 \%$ and $20 \% \mathrm{O}_{2}$. B. Cell viability following Tempol treatment was assessed by clonogenic assay in $786-0$ cells. C. Effect of Tempol $(1 \mathrm{mM})$ on cell proliferation in 786-0 and UOK220 cells. D. The effect of Tempol $(5 \mathrm{mM})$ on the anchorage-independent growth ability of 786-0 cells was assessed by soft-agar colony formation assay. 
with methanol/acetic acid (3:1), stained with crystal violet, counted (colonies $>50$ cells), and survival was corrected for the plating efficiency of untreated controls.

\section{RT-PCR.}

Total RNA was extracted using RNeasy minin kit (Qiagen, Valencia, CA) and cDNA was prepared with High Capacity cDNA Reverse Transcription kit (Applied Biosystem). RT-PCR was performed using Platinum SYBR Green qPCR SuperMix-UDG (Invitrogen).

\section{RNA Mobility Shift Assays}

Gel retardation assays were performed as follows: cell lysates were prepared in an anaerobic chamber in oxygen-depleted lysis buffer containing $10 \mathrm{mM}$ Hepes (pH 7.2), $3 \mathrm{mM} \mathrm{MgCl} 2,40 \mathrm{mM} \mathrm{KCl,} \mathrm{5 \%} \mathrm{glycerol,} 0.2 \%$ Nonidet P-40, $5 \mathrm{mM}$ DTT, $1 \mathrm{mM}$ the protease inhibitor AEBSF, $10 \mu \mathrm{g} / \mathrm{ml}$ Leupeptin and Complete EDTA-free protease inhibitor mixture (Roche Applied Science). Lysate $(x \mu \mathrm{l})$ containing $10 \mu \mathrm{g}$ of total protein was added to $(12.5-x) \mu l$ of bandshift buffer containing $25 \mathrm{mM}$ Tris- $\mathrm{HCl}(\mathrm{pH} 7.5)$ and $40 \mathrm{mM} \mathrm{KCl}$. The samples were incubated for $5 \mathrm{~min}$ at room temperature (RT) with $12.5 \mu \mathrm{l}$ of a reaction mixture containing $20 \%$ glycerol, 0.2 units $/ \mu 1$ Super RNAsine (Ambion), $0.6 \mu \mathrm{g} / \mu \mathrm{l}$ yeast t-RNA, $5 \mathrm{mM}$ DTT, and $20 \mathrm{nM} 32 \mathrm{P}$-labeled IRE from human ferritin $\mathrm{H}$ chain gene in $25 \mathrm{mM}$ Tris- $\mathrm{HCl}(\mathrm{pH} \mathrm{7.5)}$ and $40 \mathrm{mM} \mathrm{KCl}$. A measure of $20 \mu \mathrm{l}$ of this reaction mixture was loaded into a $10 \%$ acrylamide/TBE gel, which was run at $200 \mathrm{~V}$ for $4 \mathrm{~h}$, and then the gel was fixed, dried, and exposed for autoradiography.

\section{Determination of $\mathrm{Fe}^{+}$}

The content of ferrous ion was assessed using Iron Assay Kit (Biovision, Milpitas, CA) following the manufacturer instructions and without iron reducers. $\mathrm{Fe}^{2+}$ contents were measured at $593 \mathrm{~nm}$ using a microplate reader.

\section{Anchorage-independant colony formation assay}

The ability of 786-0 cell line to form anchorageindependent colonies was assessed by soft-agar colony formation assay. Two layered agarose gels of $0.5 \%$ (bottom) or $0.4 \%$ (top) low melting agarase gels were pored into $60 \mathrm{~mm}$ dishes. Two hundred thousands 7860 cells were added to the top layer and cultured until colonies were formed (about 3 weeks). Colonies with a diameter of $>0.1 \mathrm{~mm}$ were then counted in 5 random high-power fields using a phase contrast microscope.

\section{Statistics}

All values are expressed as mean \pm Standard Error. All experiments were performed three times. Values were compared using the Student-Newman-Keul's test. $\mathrm{P}<0.05$ was considered significant.

\section{REFERENCE}

1. Siegel R, Naishadham D, Jemal A. CA Cancer J Clin. 2012; 62:

2. Latif F, Tory K, Gnarra J, Yao M, Duh FM, Orcutt ML, Stackhouse T, Kuzmin I, Modi W, Geil L, . Science. 1993; 260: 1317-1320.

3. Gnarra JR, Lerman MI, Zbar B, Linehan WM. Sem Oncol. 1995; 22: 3-8.

4. Nickerson ML, Jaeger E, Shi Y, Durocher JA, Mahurkar S, Zaridze D, Matveev V, Janout V, Kollarova H, Bencko V, Navratilova M, Szeszenia-Dabrowska N, Mates D, Mukeria A, Holcatova I, Schmidt LS, Toro JR, Karami S, Hung R, Gerard GF, Linehan WM, Merino M, Zbar B, Boffetta P, Brennan P, Rothman N, Chow WH, Waldman FM, Moore LE. Clin Cancer Res. 2008; 14: 4726-4734.

5. Jaakkola P, Mole DR, Tian YM, Wilson MI, Gielbert J, Gaskell SJ, Kriegsheim A, Hebestreit HF, Mukherji M, Schofield CJ, Maxwell PH, Pugh CW, Ratcliffe PJ. Science. 2001; 292: 468-472.

6. Kaelin WG, Jr. Nature Reviews Cancer. 2002; 2: 673-682.

7. Maxwell PH, Wiesener MS, Chang GW, Clifford SC, Vaux EC, Cockman ME, Wykoff CC, Pugh CW, Maher ER, Ratcliffe PJ. Nature. 1999; 399: 271-275.

8. Ohh M, Park CW, Ivan M, Hoffman MA, Kim TY, Huang LE, Pavletich N, Chau V, Kaelin WG. Nat.Cell Biol. 2000; 2: 423-427.

9. Smaldone MC, Maranchie JK. Urol.Oncol. 2009; 27: 238245.

10. Krieg M, Haas R, Brauch H, Acker T, Flamme I, Plate KH. Oncogene. 2000; 19: 5435-5443.

11. Sufan RI, Jewett MA, Ohh M. Am.J.Physiol Renal Physiol. 2004; 287: F1-F6.

12. Raval RR, Lau KW, Tran MG, Sowter HM, Mandriota SJ, Li JL, Pugh CW, Maxwell PH, Harris AL, Ratcliffe PJ. Mol.Cell Biol. 2005; 25: 5675-5686.

13. Maranchie JK, Vasselli JR, Riss J, Bonifacino JS, Linehan WM, Klausner RD. Cancer Cell. 2002; 1: 247-255.

14. Kondo K, Klco J, Nakamura E, Lechpammer M, Kaelin WG, Jr. Cancer Cell. 2002; 1: 237-246.

15. Shen C, Beroukhim R, Schumacher SE, Zhou J, Chang M, Signoretti S, Kaelin WG, Jr. Cancer Discov. 2011; 1: 222235.

16. Zimmer M, Ebert BL, Neil C, Brenner K, Papaioannou I, Melas A, Tolliday N, Lamb J, Pantopoulos K, Golub T, Iliopoulos O. Mol.Cell. 2008; 32: 838-848. 
17. Kong HS, Lee S, Beebe K, Scroggins B, Gupta G, Lee MJ, Jung YJ, Trepel J, Neckers L. Mol.Pharmacol. 2010; 78: 1072-1078.

18. Sanchez M, Galy B, Muckenthaler MU, Hentze MW. Nat. Struct.Mol.Biol. 2007; 14: 420-426.

19. Ghosh MC, Tong WH, Zhang D, Ollivierre-Wilson H, Singh A, Krishna MC, Mitchell JB, Rouault TA. Proc.Natl. Acad.Sci.U.S.A. 2008; 105: 12028-12033.

20. Rini BI. Cancer. 2009; 115: 2306-2312.

21. Stillebroer AB, Mulders PF, Boerman OC, Oyen WJ, Oosterwijk E. Eur.Urol. 2010; 58: 75-83.

22. Chiavarina B, Martinez-Outschoorn UE, Whitaker-Menezes D, Howell A, Tanowitz HB, Pestell RG, Sotgia F, Lisanti MP. Cell Cycle. 2012; 11: 3280-3289.

23. Charloux C, Paul M, Loisance D, Astier A. Free Radic.Biol. Med. 1995; 19: 699-704.

24. Meyron-Holtz EG, Ghosh MC, Rouault TA. Science. 2004; 306: 2087-2090.

25. Sourbier C, Massfelder T. Cancer Lett. 2006; 240: 170-182.

26. Manisterski M, Golan M, Amir S, Weisman Y, Mabjeesh NJ. Cell Cycle. 2010; 9: 3723-3729.

27. McDonald PC, Winum JY, Supuran CT, Dedhar S. Oncotarget. 2012; 3: 84-97.

28. Ellis LM, Hicklin DJ. Nat.Rev.Cancer. 2008; 8: 579-591.

29. Roe JS, Kim HR, Hwang IY, Ha NC, Kim ST, Cho EJ, Youn HD. Cell Cycle. 2011; 10: 3920-3928.

30. Demidenko ZN, Blagosklonny MV. Cell Cycle. 2011; 10: 1557-1562.

31. Culver C, Melvin A, Mudie S, Rocha S. Cell Cycle. 2011; 10: $1249-1260$.

32. Anglard P, Trahan E, Liu S, Latif F, Merino MJ, Lerman MI, Zbar B, Linehan WM. Cancer Res. 1992; 52: 348-356.

33. Sourbier C, Lindner V, Lang H, Agouni A, Schordan E, Danilin S, Rothhut S, Jacqmin D, Helwig JJ, Massfelder T. Cancer Res. 2006; 66: 5130-5142. 